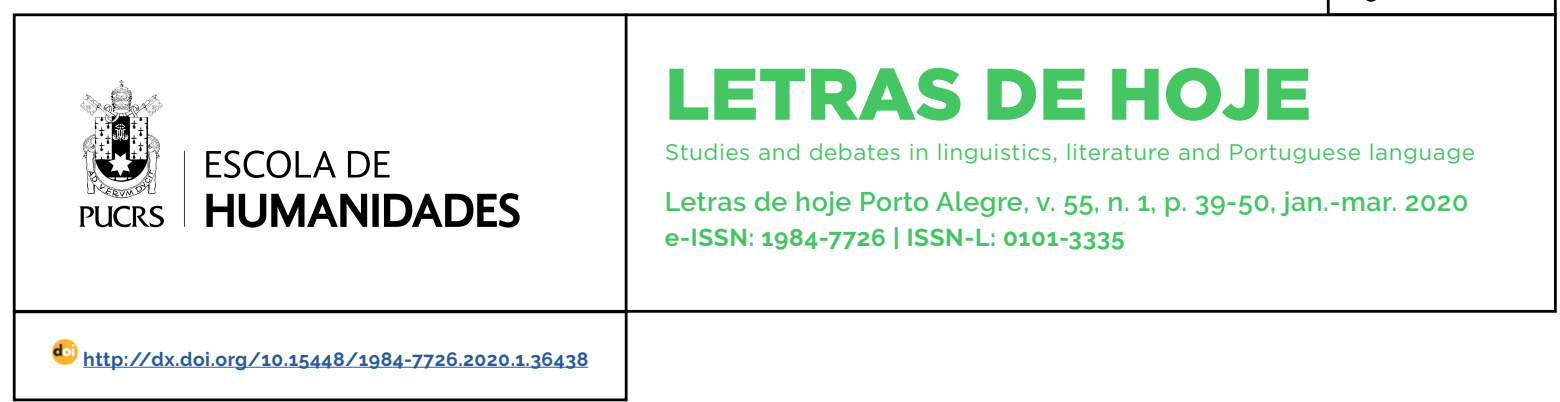

\title{
Texto, imagem e visualidade na literatura contemporânea brasileira
}

\author{
Text, image, visuality in contemporary Brazilian literature \\ Texto, imagen y visualidad en la literatura brasileña contemporánea
}

\author{
Alex Martoni ${ }^{1}$ \\ orcid.org/0000-0001-5066-468X \\ alexmartoni@cesjf.br
}

Recebido em: 15 nov. 2019 Aprovado em: 19 nov. 2019 publicado em: 14 abr. 2020.

\section{(c) (1)}

Artigo está licenciado sob forma de uma licença Creative Commons Atribuição 4.0 Internacional.
Resumo: O aumento significativo, nas últimas décadas, da produção de obras literárias fortemente marcadas pela inclusão de fotografias, pela apropriação e colagem de documentos, e por manipulações gráficas e tipográficas, dentre outras operações realizadas nos niveis textual, paratextual e perigráfico, tem exigido um reexame do modo como nos aproximamos analiticamente das mesmas. Se pensar na relação literatura e imagem significava, predominantemente, refletir sobre a produção de imagens poéticas por meio de tropos linguísticos, os processos crescentes de fixação de imagens e outras formas de visualidade na página impressa exigem hoje do leitor a consideração da literatura como um objeto complexo, marcado pelo trânsito de linguagens e por modos técnicos de articulação do sentido. É dentro dessa perspectiva que este artigo buscará mapear as condições de emergência desse fenômeno no âmbito da literatura contemporânea brasileira e propor algumas formas de articulação analitica entre literatura, imagem e visualidade hoje.

Palavras-chave: Literatura contemporânea brasileira. Texto. Imagem. Visualidade.

Abstract: The significant increase, in recent decades, of the production of literary works strongly marked by the inclusion of photographs, the appropriation and collage of documents, and graphic and typographic manipulations, among other operations carried out at the textual, paratextual and perigraphic levels, has required a reexamination as we approach analytically them. If thinking about the relationship between literature and image meant predominantly reflecting on the production of poetic images through linguistic tropes, the increasing processes of image fixation and other forms of visuality on the printed page today require the reader to consider literature as a complex object, marked by the transit of languages and by technical modes of articulation of meaning. It is within this perspective that this article will seek to map the emergency conditions of this phenomenon within the contemporary Brazilian literature and propose some forms of analytical articulation between literature, image and visuality today.

Keywords: Contemporary Brazilian literature. Text. Image. Visuality.

Resumen: El aumento significativo, en las últimas décadas, de la producción de obras literarias fuertemente marcadas por la inclusión de fotografias, la apropiación y el collage de documentos, y las manipulaciones gráficas y tipográficas, entre otras operaciones realizadas a nivel textual, paratextual y perigráfico, ha requerido una nueva mirada a cómo nos acercamos analíticamente a ellos. Si pensar en la relación entre literatura e imagen significaba reflexionar predominantemente sobre la producción de imágenes poéticas a través de tropos lingüisticos, los crecientes procesos de fijación de imágenes y otras formas de visualidad en la página impresa hoy requieren que el lector considere la literatura como un objeto complejo, marcado por el tránsito de lenguajes y por modos técnicos de articulación de significado. Es dentro de esta perspectiva que este artículo buscará mapear las condiciones de emergencia de este fenómeno dentro de la literatura brasileña contemporánea y propondrá algunas formas de articulación analitica entre literatura, imagen y visualidad en la actualidad.

Palabras clave: Literatura contemporánea brasileña. Texto. Imagen. Visualidad. 


\section{Introdução}

O aumento significativo, nas últimas décadas, da produção de obras literárias fortemente marcadas pela inclusão de fotografias, pela colagem de documentos e pela manipulação tipográfica, dentre outras operações realizadas nos niveis textuais, paratextuais e perigráficos, tem exigido um reexame das categorias tradicionais que empregamos na análise da própria literatura, como autor, livro, poesia, gênero literário e, até mesmo, literatura: "Uma literatura fora de si" (BRIZUELA, 2014), "Literatura expandida" (FIGUEIREDO, 2017) e "Formas da impertinência" (GARRAMUÑO, 2014) são algumas das rubricas que têm sido empregadas no intuito de circunscrever práticas de escrita que envolvem uma parcela significativa da produção da literatura contemporânea brasileira, como a de Laura Erber, Nuno Ramos, Luiz Ruffato, Victor Heringer, Bernardo Carvalho, Ricardo Lisias e Carlito Azevedo, dentre outros². Embora seja possivel traçar uma linha de continuidade entre as formas de escrita desenvolvidas hoje e aquelas que remontam às experiências vanguardistas do final do século XIX e início do $X X$, o desenvolvimento das tecnologias digitais, nas últimas décadas, influiu decisivamente em um sensivel aumento quantitativo e qualitativo dos modos como literatura, imagem e visualidade se tocam na tela ou na página impressa.

$\mathrm{Na}$ medida em que esses fenômenos expandem a abrangência do literário e exigem a consideração do trânsito de linguagens, mídias e materialidades no seu exame, nos interessa indagar: como pensar as complexas relações entre literatura, imagem e visualidade no âmbito da literatura contemporânea brasileira? De que forma essas novas tecnologias influem na formação de uma sensibilidade intermedial dos escritores e que novas possibilidades representativas e de construção de sentidos elas oferecem? Buscarei refletir sobre essa questão em quatro momentos. No primeiro, procurarei compreender a importância da noção de imagem para a própria teoria da literatura e suas expansões de sentido no âmbito da literatura brasileira atual; no segundo, tentarei mapear as condições de emergência desse fenômeno, assim como os seus reflexos no âmbito dos estudos literários. Proporei também, em caráter experimental, a possibilidade de se pensar as relações do escritor contemporâneo com as novas tecnologias de escrita na clave de uma sensibilidade intermedial. As duas partes subsequentes serão dedicadas a exercícios de leitura que permitam colocar em relevo as complexidades que envolvem análises articuladas entre texto, imagem e visualidade. Para tal, tomaremos como referência uma passagem do romance $O$ amor no tempo dos homens avulsos (2016), de Victor Heringer; e algumas páginas de Eles eram muitos cavalos (2013), de Luiz Ruffato.

\section{I magem na literatura}

A fricção entre os vocábulos literatura e imagem abre caminhos que se bifurcam. Podemos pensar em textos que descrevem ou evocam imagens; em imagens que se formam à consciência a partir da decodificação de signos verbais; em trechos de obras literárias transpostas para outras midias; e, ainda, em páginas ou telas que justapõem textos, ilustrações, reproduções de pinturas ou de fotografias, dentre outras bifurcações ainda possiveis. É dentro dessa perspectiva que, buscando delinear de forma mais precisa o nosso problema, minha questão de partida será: no que pensamos quando nos propomos a refletir sobre os desdobramentos relativos à presença da imagem na literatura?

Tradicionalmente, a noção de imagem verbal cumpriu um papel fundamental enquanto categoria distintiva do literário, isto é, sabe-se que um texto é literário pela sua competência de produzir um determinado tipo de imagem à consciência. Nesse sentido, quando empregamos termos como imagem literária, imagem poética, figura e tropo, temos em mente uma forma de organização da linguagem cujo efeito provocado à consciência, a partir do ato da leitura, se

2 A dissertação de mestrado Quando a palavra não basta: a presença do escritor em romances contemporâneos brasileiros (JUNGBLUT, 2019), de Helena Jungblut, apresenta um substancial mapeamento dessas operações de escrita no horizonte contemporâneo. 
descolaria do tipo de experiência proporcionada por textos ditos "não literários". É sintomático que essa concepção irrompa, não por acaso, com a emergência da própria noção de literatura como forma escrita, como nos conta Gilberto Mendonça Telles:

\begin{abstract}
No contexto oralizante, a "imagem" era um processo mneumotécnico para se lembrar de versos a serem recitados e, também, uma forma de representar mais vivamente a linguagem do rapsodo. Era portanto fortemente repetida como "deixa", como "gancho" (como se diz hoje) para que o narrador não se perdesse [...] com a escrita a imagem passou a ocupar o centro da criação poética, introduzindo vários sentidos e representando coisas dificeis de serem ditas de outra maneira (TELLES, 2005, p. 108).
\end{abstract}

A produção da imagem literária, portanto, envolveria um conjunto de estratégias na organização da linguagem que visaria à produção de uma determinada qualidade de sentido. De um modo geral, essa concepção trabalha com a noção de que a imagem poética produziria representações de objetos concretos à consciência, em oposição à ideia, de natureza mais abstrata. A teoria da literatura, ao longo do século XX, ampliou essa concepção, situando-a, como nos mostra Octavio Paz, no âmbito das operações realizadas no nível da retórica:

designamos com a palavra imagem toda forma verbal, frase ou conjunto de frases que o poeta diz e que juntas compõem um poema. Essas expressões verbais foram classificadas pela retórica e se chamam comparações, símiles, metáforas, jogos de palavras, paronomásias, símbolos, alegorias, mitos e fábulas etc. (PAZ, 2012, p. 104).

A perspectiva apontada por Octavio Paz nos permite afirmar, portanto, que, tradicionalmente, a noção de imagem na literatura se assentou fortemente na noção de significante enquanto portador do sentido. Em grande medida, o que a reflexão do ensaista mexicano revela é o peso da noção de signo concebida por Ferdinand de Saussure na análise da poesia. Lembremos que, em sua definição de signo, o linguista suiço, por razões históricas totalmente justificáveis, não considera a dimensão visual do próprio significante como uma instância produtora de sentido, posição que se evidencia no modo como Saussure opõe as imagens visuais à sua noção de signo: "os homens poderiam também ter escolhido o gesto e empregar imagens visuais em lugar de imagens acústicas" (SAUSSURE, 2006, p. 17). Essa concepção está amplamente espraiada na crítica literária do século XX. Ao refletir sobre a natureza da imagem poética, o ensaísta brasileiro Alfredo Bosi, por exemplo, salienta que: "A superfície da palavra é uma cadeia sonora" (BOSI, 2010, p. 29). Para além do estrito campo da poesia, a noção de imagem na literatura enquanto forma como o signo influi na produção de representação à consciência também foi empregada como forma de conceber a maneira como eventos e figuras de uma narrativa se fixam em nossa consciência. Mikhail Bakhtin afirmava, nesse sentido, que "A representação literária, a 'imagem' do objeto, pode penetrar neste jogo dialógico de intenções verbais que se encontram e se encadeiam nele" (BAKHTIN, 2010, p. 87). Já no âmbito dos estudos de recepção, Wolfgang Iser assevera que "A imagem é [...] a categoria básica da representação" (ISER, 1999, p. 58). Ao fim e ao cabo, embora produzidos em territórios históricos e teóricos distintos, parece haver um fundamento epistemológico comum no que diz respeito à noção de imagem na literatura: ela corresponderia a um fenômeno produzido nesses espaços de encontro entre processo de decodificação de signos verbais e consciência representacional.

Ao contrário do que se possa apressadamente intuir, o argumento que pretendo construir, a partir deste ponto, não será feito sobre as ruinas do anterior, isto é, não se busca negar a relevância e produtividade da imagem verbal, mas colocar em relevo a necessidade de se considerar uma outra dimensão do problema: a relação dessas imagens com imagens gráficas e recursos de visualidade inseridos na superfície da página impressa. Os processos que de inclusão de fotografias, de apropriação e colagem de documentos, de manipulação gráfica e tipográfica, dentre outras operações realizadas nos niveis textuais, paratextuais e perigráficos, têm exigido 
um reexame das categorias tradicionais que empregamos na análise da própria literatura. Nesse sentido, falar em imagem na literatura implica conceber o literário como algo que não abrange mais somente o signo verbal e a sua potencialidade de produção de representações à consciência, mas também os deslizamentos e expansões de sentido que o mesmo opera ao ser friccionado com imagens gráficas e recursos variados que conferem determinada forma de visualidade à página impressa. Nesse sentido, gostaria de propor, na próxima seção, o exame do seguinte problema: quais são as condições de emergência dessas práticas e em que medida elas estariam relacionadas com o modo como as tecnologias contemporâneas influem na formação de uma sensibilidade intermedial dos escritores?

\section{Condições de emergência de uma sensibilidade intermidial}

O desenvolvimento e a difusão de novos dispositivos técnicos de produção, processamento e circulação de imagens, ocorrido nas últimas décadas do século XX, e o seu impacto do âmbito de nossas práticas sociais, culturais e estéticas engendrou uma autopercepção fundamentada na ideia de que viveriamos sob a égide de uma civilização da imagem ou cultura da imagem.

À guisa de uma incursão pelos fundamentos epistemológicos que incendeiam os debates em torno do tema ${ }^{3}$, interessa-me salientar como a própria existência de tais querelas evidenciam em que medida o problema do modo como nos relacionamos com as imagens foi se configurando como uma questão central para nós hoje. Visual culture, visual studies, Bildwissenchat foram algumas das rubricas acadêmicas que emergiram como projetos institucionais voltados à constituição de um campo interdisciplinar dirigido ao estudo das imagens.

Sob a perspectiva dos estudos de literatura, essa condição cultural fortemente marcada pela circulação de imagens somada ao aumento substancial das práticas de escrita voltadas à incorporação de fotografias, documentos, dentre outras inscrições visuais na página impressa, impõem uma perda de autonomia do signo verbal como locus exclusivo do literário. Nesse sentido, para Karl Erik Schollhammer e Heidrun Krieger Olinto,

Não parece mais possivel isolar a obra literária de sua inserção numa rede complexa de significação cultural predominantemente visual, identificada com frequência como a "cultura da imagem" e sustentada pelos meios de comunicação e pela expansão da realidade virtual (OLINTO; SCHOLLHAMMER, 2005, p. 9).

A consciência crescente de que as práticas de escrita, contemporaneamente, estão inscritas em uma rede complexa de significação cultural predominantemente visual, como salientam Schollhammer e Olinto, impõe desafios tanto na ordem de sua descrição conceitual quanto no desenvolvimento de metodologias que permitam a sua abordagem: como integrar, por exemplo, regimes de produção de sentido distintos, como a palavra e a imagem, na análise literária? De que forma compreender como operações gráficas e tipográficas alteram os valores sintático e semântico do próprio texto? Esse conjunto de indagações no domínio metodológico deve, contudo, ser precedido pelo seguinte problema: como descrever conceitualmente o objeto em questão?

A professora e ensaísta Vera Lúcia Foullain de Figueiredo propõe o termo literatura expandida como modo de circunscrição desse fenômeno no qual "o aprimoramento das tecnologias eletrônicas e digitais, os deslocamentos e expansões que abalam as especificidades de cada meio de expressão" (FIGUEIREDO, 2017, p. 97). Natalia Brizuela, professora e ensaista da universidade de Berkeley, Estados Unidos, também investe na rubrica "expansões da literatura" (BRIZUELA, 2014, p. 31) como modo de ancoragem de uma produção literária fortemente marcada por

\footnotetext{
A despeito da tese de que viveriamos em uma civilização da imagem, o filósofo francês Gilles Deleuze propõe que os esquematismos sensório-motores de tais imagens nos definiriam melhor como uma civilização do clichê (DELEUZE, 2005). Já no âmbito da Visual Culture. W.T.J. Mitchell escreve um influente artigo por meio do qual busca sistematizar as críticas dirigidas ao campo teórico que busca fundar, tentando, ao mesmo tempo, rebatê-las também sistematicamente (MITCHELL, 2005).
} 
"cruzamentos, passagens e intermediações que levaram as artes para as desestruturações de si mesmas" (BRUZUELA, 2014, p. 15). A ensaísta argentina Florencia Garramuño, por sua vez, propõe pensar o problema em negativo, isto é, conceber certas tendências da produção estética contemporânea como "formas diversas de não pertencimento" (GARRAMUÑO, 2014, p. 91). Ao fim e ao cabo, o fundamento dos esforços descritivos de Foullain, Brizuela e Figueiredo parece residir em uma concepção do literário como algo cediço, movente. Nesse sentido, cabe-nos indagar sobre o papel desempenhado por aquele que promove esses deslizamentos, o escritor.

O escritor contemporâneo - proponho aqui uma tese de caráter experimental - está inscrito em um horizonte de sensibilidade intermedial, isto é, seus gestos de apropriação, transformação e atravessamentos de signos verbais e gráficos apresentam, como condição de possibilidade, uma atividade imaginativa que interage, diuturnamente, com o manancial de imagens disponiveis na internet, com as ferramentas de edição de softwares e com a própria construção cultural da visão operada pelas formas socias de uso dos dispositivos técnicos e suas formas de programação do próprio gesto de escrita. Friedrich Nietzsche já tinha expressado a sua suspeita acerca do impacto das novas tecnologias de escrita no campo do pensamento por meio de uma frase redigida em uma carta de 1882: "Nossa ferramenta de escrita trabalha juntamente com o nosso pensamento" (KITTLER, 2019, p. 278). Ao refletir, por sua vez, sobre o impacto das inovações técnicas no âmbito da produção cultural no Brasil no início do século XX, a ensaísta Flora Süssekind destaca que tal fenômeno repercutiu

no cotidiano e na transformação da sensibilidade dos produtores culturais mais atuantes no Brasil da virada do século e dos dois primeiros decênios do século $X X$, chegando mesmo a marcar decisivamente - por contraste, imitação e estilização - sua técnica literária (SÜSSEKIND, 2006, p. 17).
De fato, o desenvolvimento do linotipo, da fotografia, do cinematógrafo e do fonógrafo e do gramofone, dentre outras tecnologias do século XIX, parece ter influido decisivamente na técnica literária. As autorreferências tipográficas em Memórias póstumas de Brás Cubas, de Machado de Assis, publicado em 1881; a exploração da sintaxe espacial, em Um lance de dados (1897), de Mallarmé e Palavra em liberdade (1913) Filippo Marinetti; a inserção de fotografias nas páginas do romance Nadja (1928), por André Breton; os jogos entre as dimensões simbólica e icônica da palavra, nos caligramas de Guilhaume Apollinaire e nas experiências realizadas pelos concretistas brasileiros, dentre muitas outras, parecem dar consistência à tese de que a sensibilidade do artista é, em grande parte, plasmada pelas relações que ele mantém com as potencialidades de produção de sentido oferecidas por diferentes meios. Nesse sentido, a produção contemporânea não se encontra em uma linha de ruptura, mas de uma continuidade matizada. A formação interdisciplinar desses escritores é, sem dúvida, pedra de toque para a constituição de uma sensibilidade que consegue operar com e entre diferentes materialidades expressivas. Veronica Stigger é crítica de arte; Laura Erber e Nuno Ramos, artistas visuais. Não obstante a formação, há também uma confessa vontade de experimentar diferentes potencialidades expressivas. O escritor Mario Bellatin fundou, no México, a Escola Dinâmica de Escritores, cujas atividades, segundo Natalia Brizuela, visam "especificamente o apagamento das fronteiras que separam as artes entre si" (BRIZUELA, 2014, p. 14); quando questionado acerca de sua relação com outras práticas artísticas, como videopoemas e instalações acústicas, Victor Heringer se definiu como um "romancista promiscuo"4: em palestra recente na Universidade Federal de Minas Gerais (UFMG), Eduardo Kac definiu seu computador como um ateliê portátil5.

Em face do contexto de emergência dessas práticas de escrita e da formação de uma

\footnotetext{
4 Em entrevista concedida a site da Revista Época. Disponivel em: https://epoca.globo.com/vida/noticia/2016/og/multiplataforma-victor-heringer-pediu-ajuda-na-rede-para-escrever-seu-novo-livro.html. Acesso em: 14 nov. 2019.

5 Esta conferência, realizada em 22 de maio de 2019, se deu no âmbito do // Colóquio internacional Escrita, som, imagem, realizado na Universidade Federal de Minas Gerais (UFMG).
} 
sensibilidade intermedial dos escritores, proporei, nas duas seções subsequentes, duas breves leituras de fragmentos de uma passagem do romance $O$ amor no tempo dos homens avulsos (2016), de Victor Heringer; e algumas páginas de Eles eram muitos cavalos (2013), de Luiz Ruffato, com o objetivo de avaliar as potencialidades representativas e de produção de sentidos a articulação entre texto, fotografia e tipografia oferece à ficção.

\section{Palavra e fotografia em 0 amor dos homens avulsos}

Tradicionalmente, os romances reservavam à fotografia lugares à margem da narrativa: capa, orelha, quarta capa, espaços que poderiam estampar tanto um retrato do autor quanto uma foto panorâmica da cidade onde se passa a história. Mas o que acontece quando a fotografia aparece impressa entre dois parágrafos, integrando o próprio fluxo da narrativa? Esta é uma questão que se impõe ao longo da leitura de O amor dos homens avulsos (2016), de Victor Heringer. Ao longo do romance, Camilo, narradorpersonagem, expõe, de forma memorialística e fragmentária, o conjunto de experiências que marcou o seu processo de crescimento e de formação em um bairro do subúrbio carioca no anos 1970. Em meio às partidas de futebol, às dificuldades para se locomover de muletas e às desconfianças sobre a suposta ligação do pai com o regime militar, a descoberta de uma paixão por Cosme, menino apadrinhado por seu pai, ganha protagonismo.

Ao longo do romance, Victor Heringer reserva à fotografia um lugar de destaque na costura da tessitura do romance. Essas fotos possuem origens diversas: arquivo pessoal do autor, bancos de fotos da internet, extraídas de outros livros ou do portfólio de fotógrafos profissionais, e se alternam com um conjunto de outros procedimentos, como a apropriação e colagem de documentos escolares e inserção de desenhos de autoria própria. Mas, retomando nossa pergunta de partida, o que acontece quando a fotografia aparece impressa entre dois parágrafos, integrando o próprio fluxo da narrativa? Gostaria de partir de um capítulo do romance de Heringer para refletir mais profundamente sobre esse problema.

\section{1}

Foi à luz do dia. Na esquina de casa. Eu me lembro do sol na testa, no couro da cabeça, $\because, ;$ nos meus braços, o suor na pele colada às muletas. A eterna neblina de poeira bege. Meu primeiro beijo.

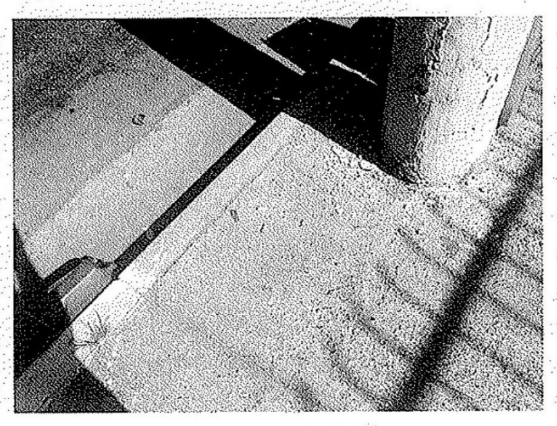

Estávamos andando, aí paramos nesse lugar da foto, que fica a quatro quartcirões daqui. A conversa não era sobre nada de mais. Parar é que foi meio atrapalhado, porque não tínhamos motivo para de repente não seguir caminhando. Foi Cosmim que pa-

91

Figura 1 - Página do capítulo 51 de O amor dos homens avulsos

Fonte: HERINGER, 2016, p. 91

A página na Figura 1 nos apresenta um fragmento do capítulo 51 de O amor dos homens avulsos. Nele, Camilo narra o episódio do primeiro beijo que recebera de Cosme. De acordo com a narrativa, "Foi à luz do dia. Na esquina de casa. Eu me lembro do sol na testa, no couro da cabeça [...]" (HERINGER, 2016, p. 91). Ambos param na esquina indicada pela foto e Cosme toma a iniciativa do beijo. Os parágrafos subsequentes, à maneira machadiana, expõem diversas impressões e associações do narrador acerca do momento vivido e, agora, rememorado.

Na medida em que se trata de um texto narrativo, a presença de uma fotografia entre dois parágrafos impõe ao leitor, inequivocamente, um esforço de articulação de sentido, de produção de causalidade temporal, de construção de um nexo sintático entre dois regimes representacionais distintos: o caráter simbólico da palavra e o indexical da fotografia. Dentro dessa perspectiva, 
o processo de deslizamento do sentido por entre parágrafo, fotografia e, novamente, parágrafo nos força à produção de nexos sintáticos entre duas formas de produção de pensamento e temporalidade distintas: a do pensamento em linha, como nos diria Vilém Flusser (2013), por meio do qual o sentido é construido no movimento linear que os olhos realizam da esquerda para a direita no processo de leitura; e do pensamento em superfície - ainda na terminologia do filósofo checo -, em que o leitor realiza uma livre varredura voltada a inspecionar a imagem. Há, pelo menos, dois desdobramentos relativos a essa interação entre as imagens verbal e gráfica que nos permitem avaliar as potencialidades representativas e de produção de sentidos que essas práticas oferecem à ficção.

Em primeiro lugar, cabe à palavra, no caso em questão, dar ancoragem à imagem. Uma fotografia em uma página possui inequivocamente um caráter polissêmico, na medida em que pode remeter o leitor a cascatas interpretativas. Não obstante essa possibilidade, na página em questão, os parágrafos que antecedem e sucedem à foto the dão ancoragem, impõem-lhe um sentido; tiram-na da impessoalidade - qualquer esquina - para lhe conferir um caráter particular, aquela em que se deu "primeiro beijo". A flutuação polissêmica da foto tem o seu fim decretado pelo dêitico: "nesse lugar da foto" (HERINGER, 2016, p. 91). Essa ancoragem nos leva para um segundo desdobramento da relação entre palavra e imagem na página do romance de Heringer: o modo como o caráter ontológico da fotografia influi na construção de sentidos sobre a narrativa.

$\mathrm{Na}$ medida em que o beijo se deu em uma esquina que nos é, concomitantemente, apresentada por meio de uma imagem, a natureza indexical da fotografia acaba projetando sobre o texto o seu caráter ontológico cediço entre o mimético e o artifício. Como nos mostrou Roland Barthes (2012), a indexicalidade impõe, inexoravelmente, à fotografia, caráter de documento, um isto foi; uma câmera esteve ali, produziu uma escrita de luz em um tempo e um espaço. Ou seja, o lugar da foto existe, independentemente de sua relação com a tessitura da narrativa. Contudo, o modo como ela está inserida na página impressa aponta menos para uma suposta construção de um fundo de veracidade à história, e mais para a possibilidade de ampliar potencialidades imaginativas no processo de leitura a partir de processos de apropriação e ressignificação que o texto, enquanto ancoragem, impõem ao real. Fotografias que o autor tirava do chão enquanto caminhava por São Paulo se transfiguram em elementos que constituem as memórias de Camilo. Nesse sentido, sua organização dentro da narrativa, além de um senso de montagem, produz, a partir dela, um processo de ressignificação, pois, de acordo com Natalia Brizuela,

\section{Tipografia e visualidade em Eles eram muitos cavalos}

Com os cinco volumes de O inferno provisório (2016) e Eles eram muitos cavalos (2013), o escritor mineiro Luiz Ruffato opera uma radical entre os regimes de legibilidade e visibilidade. As páginas de Eles eram muitos cavalos, particularmente, nos apresentam 70 short cuts da vida cotidiana de moradores da cidade de São Paulo situados em um único dia: 9 de maio de 2000, a partir de uma alternância vertiginosa nas formas de diagramação e nas escolhas tipográficas. Nesse sentido, cabe-nos questionar como experiências de configurações visuais, tais como a apresentada pela página abaixo, expandem as formas de produção de sentido no horizonte da prosa ficcional contemporânea: 
as costas, $A i !$, as escadeiras, $U i !$, as pernas, $A i !$ !, Ui!, sem posição, Alá, vovó, alá as luzes de São o filho esperando Tantos anos! ganhar a vida em Sampaulo, no Brejo Velho Duas vezes só, voltou, meu Deus, e isso em solteiro, depois, apenas os retratos carreavam notícias, o emprego, a namorada-agora-esposa, eles dois, a casa descostelada, os netos, e vamos entāo esperar a senhora para passar o Dia das mäes com a nossa família e todos vamos ficar muito felizes nāo preocupa nāo gue en vou buscar a senhora na rodoviária lembranças a todos do a bexiga caxumbenta, o intestino goguento, como ler o olho do filho?, saber se é feliz no trabalho, no casamento, se, mas $A i$, a bexiga, a barriga, as costas, $A i$ !', as escadeiras, $U i$ !, as pernas, $A i$ !', $U i$ !, sem posição $\mathrm{Na}$ rodoviária, de pé, esfrega as mãos.

Figura 2 - Página de Eles eram muitos cavalos Fonte: RUFFATO, 2013, p. 19.

Diante de uma página como a da Figura 2, a pergunta de partida deve ser: o que vemos quando lemos? À primeira vista, parece se tratar de uma indagação completamente descabida, tendo em vista que o ato de ler traz como précondição o próprio ato de ver; isto é, o ato cognitivo de ler, de decodificar signos verbais, depende do ato perceptivo de ver, de perceber formas inscritas no mundo sensivel. Contudo, se nos impusermos uma espécie de inspeção interior no curso do ato da leitura, perceberemos que o nosso olhar é tomado por uma espécie de vertigem que borra os contornos da superfície do significante para que possamos mergulhar na profundidade do significado do texto.

Esse gesto perceptivo não é natural; foi construido historicamente. Com a revolução na cultura impressa, os tipógrafos estabeleceram uma ética da invisibilidade tipográfica, isto é, um princípio no qual os tipos só cumpririam a sua função com eficiência quando a única coisa que o leitor pudesse "ver" seria a mensagem do texto, o que significa dizer que a materialidade de suas conformações visuais passa a ser compreendida como um tipo de ruido que deveria ser suprimido a fim de que o nosso olhar pudesse ser tomado por aquela espécie de vertigem que borra os contornos da superfície do significante para que o significado profundo pudesse emergir. É dentro dessa perspectiva que o texto de Ruffato inquieta, interrompendo o fluxo habitual da leitura. Ao nos depararmos com mudanças abruptas nas conformações tipográficas, interrompemos a leitura, este movimento ritualizado do olhar, que se desloca da esquerda para a direita; de cima para baixo. Voltamos à frase anterior, inspecionamos a página e lançamos um olhar ao título com o objetivo de buscarmos alguma justificativa para essa mudança.

O fragmento acima corresponde a uma passagem do capítulo 6 de Eles eram muitos cavalos. Nele, narrase sobre a chegada de uma senhora e de seu neto à cidade de São Paulo, depois de oito horas de uma viagem que como origem a cidade de Garanhuns, Pernambuco. A falta de unidade visual que salta aos olhos evidencia o modo como Luiz Ruffato alterna, de forma radicalmente breve, diferentes formas tipográficas: vemos palavras inscritas nas formas standard, negrito, itálico e manuscrita. É nesse sentido que, no romance do escritor mineiro, o significante não deve ser pensado somente como o portador do sentido, mas também como o próprio configurador do sentido. A essa propriedade, Johanna Drucker denominou enunciação tipográfica, 
isto é, "A capacidade da representação tipográfica de manipular o valor semântico do texto através da sua visualidade" (DRUCKER, 1994, p. 94). É importante salientar que a noção de enunciação, aqui, sofre uma expansão de sua abrangência. Se a enunciação, enquanto ato concreto de realização da língua por meio da fala é uma ação intersubjetiva inscrita por categorias como tempo, lugar, relações sociais, objetivos visados e papeis representados pelos interlocutores, a visualidade dos tipos, quase como um dêitico, inscreve condições históricas particulares de produção do enunciado. Lembremos também, a esse respeito, como em A arqueologia do saber, Michel Foucault se perguntava sobre o potencial enunciativo dos caracteres de chumbo utilizados para imprimir os livros; questão a qual ele responde afirmando que "O enunciado é sempre apresentado através de uma espessura material [...] mas ela não lhe é dada em suplemento, uma vez bem estabelecidas todas as suas determinações: em parte ela o constitui" (FOUCAULT, 2012, p. 103). A flutuação vertiginosa nos padrões de diagramação e nos modelos tipográficos, ao longo do romance, influi, fundamentalmente, sobre três aspectos que o compõem: a multiplicidade de gêneros, a construção polifônica e a caracterização dos personagens.

No fragmento de texto em questão, as formas tipográficas se constituem como um sistema de distinção espaço-temporal das vozes que nos são apresentadas. A forma standard é empregada para a voz do narrador em terceira pessoa onisciente; os itálicos indicam o pensamento da avó; os negritos, o discurso do neto; e a manuscrita, a carta que avó recebera do filho. Há, contudo, passagens em discurso indireto livre que atravessam e complexificam esse sistema. Nesse sentido, um primeiro desdobramento visivel da exploração que Ruffato faz do processo de enunciação tipográfica é dar visibilidade ao aspecto polifônico do romance.

Outro aspecto decorrente desse processo de enunciação tipográfica consiste no modo como a forma tipográfica contribui no modo como construímos imagens à consciência dos próprios personagens. Esse aspecto se evidencia na oscilação no uso das formas que emulam a letra cursiva, como os exemplos a seguir:

Sem camisa, a calça de moletom cinza arrasta o chinelo-raider pelo sinteco até a cozinha. Nas trempes engorduradas do fogão-a-gás, um coador engasgado de pó-de-café mergulha num bule verde-escuro empipocado de florzinhas brancas, a espuma aerada do leite fervido cobre o campo negro do tefal, uma tampa assenta-se deselegante sobre a garganta da panela-de-pressão, restos de uma sopa-knorr galinha-caipira. Na porta da geladeira, fixado por ímãs (um abacate, um chuchu e a propaganda de uma farmácia), um bilhete:

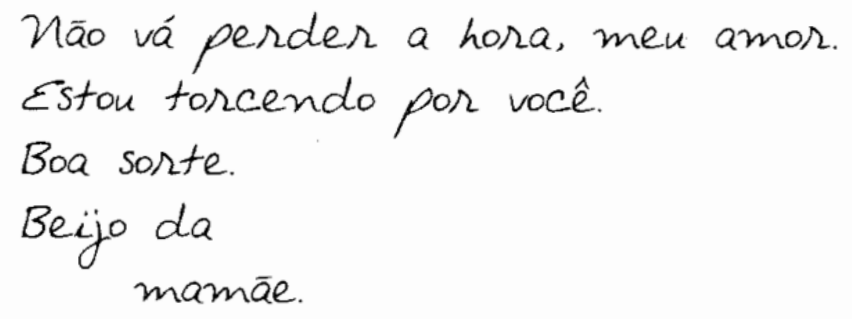

Figura 3 - Página de Eles eram muitos cavalos

Fonte: RUFFATO, 2013, p. 35. 


\section{Carta}

\section{Guidoval, 2 de maio de 2000}

Querido Paulino, meu filho,

Escrevo-the essas mal thaçadas linhas para dar noticias nossas e também receber as suas. Oqui graças a Deus vai indo tudo bem. O seu pai é que anda acamado por causa de que outro dia estrepou o pé num toco que estava enterrado no meio da vargem. E você sabe $\theta$ quanto $\theta$ seu pai é teimoso. $O$ cabeça- dura não queria ir no posto de saúde mas aí o pé pegou a inchar, quase deu tétano. Oi ele foi muito a contragosto e agora está deitado, o pé deste tamanho, vermelho que sé vendo...

E você, tem se alimentado direitinho? Ainda ontem o gé Gomes, lembra dele? aquele que morava lá pelas bandas do gezim Francisco, ele agora botou casa de comércio está chique que só vendo, ele perguntou por você. Diz ele que jogou muita bola com você lá no campo do gezim Francisco. Ele acha que você até chegou a namorar a Sueli irmã dele, que casou e mora em Ponte Nova.

Tem feito muito frio ai? Qqui a noite já anda exigindo uma cobertinha. Você lembra como eu passava mal nessa época do ano, quase morria? Pois não mudou nada. Quando a tarde vem caindo e sobe aquele poeiräo amarelo começa a aflição do nariz entupido, a falta de ar, a sufocação e parece que esta vez é a última, ai meu filho näo desejo esse estupor pra ninguém, nem pro pior inimigo. Você tem se agasalhado direitinho? O médico mandou fazer inalação, mas, e dinheiro pra aviar a receita? Tudo pela hora da morte.

Figura 4 - Página de Eles eram muitos cavalos

Fonte: RUFFATO, 2013, p. 91.

É interessante perceber que, embora se tratem, aqui, de tipos concebidos digitalmente e impressos por uma máquina, situado em uma zona limitrofe entre a mão e a máquina de escrever. Apresentam traços emulam a singularidade, a espontaneidade e a irregularidade formal próprias às linhas de um texto manuscrito. Essa tensão entre a mão e a máquina se torna ainda mais complexa quando posta em face das articulações entre os planos formal e o narrativo. Um personagem é uma imagem sintética das várias perspectivas através das quais ele nos é apresentado. Nesse sentido, as conformações dos tipos inscritos no romance de Ruffato contribuem na sua construção, tendo em vista que apresentam potencial de sugerir aspectos relativos ao próprio gesto da escrita e características qualitativas da voz do personagem. Corpo, escolaridade, temperamento, condição afetiva, instrumento de escrita, dentre outros aspectos, se insinuam por meio da curvatura e do delineamento das letras. Evidentemente, não se trata, aqui, de uma consideração mecanicista, como um exame grafológico, mas de chamar a atenção para a capacidade sugestiva das conformações visuais do texto. Ao fim e ao cabo, o que queremos assinalar é que, embora construídas digitalmente, a emulação das formas cursivas enriquece o modo como construimos a imagem do personagem na 
consciência, enriquecendo os modos de conceber a natureza polifônica do texto. É nesse sentido que o processo de formação de uma sensibilidade intermedial e o modo como ela amplia o horizonte de criação e de produção de sentido em um romance - o significante não assume somente o papel de portador do sentido, mas ele é o próprio configurador do sentido, o que consolida uma nova possibilidade representativa e de construção de sentidos no âmbito da ficção contemporânea.

\section{Considerações finais}

Este artigo se propôs a pensar as complexas relações entre literatura, imagem e visualidade no âmbito da literatura contemporânea brasileira. Dentro dessa perspectiva, procuramos, em primeiro lugar, perspectivar os modos como podemos pensar a noção de imagem na literatura. Em um segundo momento, tentamos mapear o contexto de emergência dessas práticas de escrita e buscamos, em caráter experimental, propor a noção de sensibilidade intermedial como forma de refletir sobre o problema. Nas duas partes subsequentes, realizamos dois exercícios de leitura, de uma passagem do romance O amor no tempo dos homens avulsos (2016), de Victor Heringer; e de algumas páginas de Eles eram muitos cavalos (2013), de Luiz Ruffato, com o objetivo de colocar em relevo as complexidades que envolvem análises articuladas entre texto, imagem e visualidade.

A riqueza do manancial oferecido pela literatura contemporânea brasileira lança muitos outros desafios: poderiamos nos questionar sobre o papel da indexicalidade da fotografia em romances plasmados sobre um fundo de veracidade, como Nove noites (2002), de Bernardo Carvalho, e Divórcio (2013), de Ricardo Lísias ou, ainda o senso de montagem e os modos expansivos nos quais a imagem comparece nas obras de Laura Erber, Nuno Ramos e Veronica Stigger. Em outra clave, outros problemas poderiam ser levantados, como, por exemplo, até que ponto as intervenções no nivel da visualidade consistem em uma estratégia de sobrevivência do romance na era da internet ou em que nivel se dá a intervenção da editora nesse processo. Poderíamos nos questionar, ainda, em chave política, em que medida essas práticas de escrita se constituem como formas singulares de ocupar o sensivel, se partirmos da noção de Jacques Rancière de que a escrita "é coisa política porque seu gesto pertence à constituição estética da comunidade" (RANCIĖRE, 2017, p. 8). Nesse sentido, o modo, portanto, como nós o ocupamos implica optar por se resignar a um modo disciplinar de ocupar esse sensivel ou subvertê-lo, fazendo produzir potências de pensamento.

Não obstante a relevância dessas questões, ao fim e ao cabo, o que se buscou colocar em evidência é a importância de refletirmos, contemporaneamente, sobre como a noção de escrita literária se expande para além do texto, abrangendo todos os tipos de signos que conferem novas formas de visualidade à página impressa: fotografias, documentos, manipulações gráficas e tipográficas, além de um conjunto de operações nos niveis paratextuais e perigráficos que pode envolver a própria conformação do livro. Desse modo, desconstrói-se, aqui, a velha máxima de que escritores não escrevem livros, escrevem textos. Espero ter deixado claro, ao longo deste artigo, a natureza equivocada dessa afirmação quando confrontada com os romances contemporâneos brasileiros.

\section{Referências}

BAKHTIN, Mikhail. Questões de literatura e de estética: a teoria do romance. São Paulo: HUCITEC, 2010.

BARTHES, Roland. A câmara clara. Rio de Janeiro: Nova Fronteira, 2012.

BOSI, Alfredo. O ser e o tempo da poesia. São Paulo: Companhia das Letras, 2010

BRIZUELA, Natalia. Depois da fotografia: uma literatura fora de si. Rio de Janeiro: Rocco, 2014. https:// doi.org/10.5335/hdtv.16n.2.6932

CARVALHO, Bernardo. Nove noites. São Paulo: Companhia das Letras, 2002. https://doi. org/10.17851/2359-0076.25.34.241-243

DELEUZE, Gilles. A imagem-tempo. São Paulo: Brasiliense, 2005.

DRUCKER, Johanna. The visible word: experimental typography and modern art, 1909 - 1923. Chicago: The University of Chicago Press, 1994. 
FIGUEIREDO, Vera Lúcia Foullain. Linguagens moventes: literatura expandida e mercado cultural: a escrita como intermidia. In: DAFLON, Claudete; GARBERO, Maria Fernanda; SANTOS, Matildes Demetrio dos. Agentes do contemporâneo. Niterói: Eduff, 2016.

FLUSSER, Vilém. Linha e superficie. In: FLUSSER, Vilém. O mundo codificado. São Paulo: Cosac Naify, 2013. https://doi.org/10.1590/s198225532013000200005

FOUCAULT, Michel. A arqueologia do saber. Rio de Janeiro: Forense Universitária, 2012.

GARRAMUÑO, Florencia. Formas da impertinência. In: GARRAMUÑO, Florencia; KIFFER, Ana. Expansões contemporâneas: literatura e outras formas. Belo Horizonte: Editora UFMG, 2014

HERINGER, Victor. O amor no tempo dos homens avulsos. São Paulo: Companhia das Letras, 2016.

ISER, Wolfgang. O ato da leitura. São Paulo: Editora 34, 1999. https://doi.org/10.5380/rv.v1i3.18076

JUNGBLUT, Helena. Quando a palavra não basta: a presenta do escritor em romances contemporâneos brasileiros. Dissertação (Mestrado) - Universidade de Santa Cruz do Sul, Santa Cruz do Sul, 2019. 216 f. https://doi.org/10.17533/udea.redin.n76a10

KITTLER, Friedrich. Gramofone, filme, Typewriter. Belo Horizonte: Editora UFMG; Rio de Janeiro: EdUERJ, 2019

LíSIAS, Ricardo. Divórcio. Rio de Janeiro: Objetiva, 2013

MITCHELL, W. T. J. Showing seeing: A critique of visual culture. In: MITCHELL, W. T. J. What do pictures want? The lives and loves of images. Chicago: The University of Chicago Press, 2005. https://doi. org/10.7208/chicago/9780226245904.001.0001

PAZ, Octavio. O arco e a lira. São Paulo: Cosac Naify, 2012.

RANCIĖRE, Jacques. Políticas da escrita. São Paulo: Editora 34, 2017

RUFFATO, Luiz. Eles eram muitos cavalos. São Paulo: Companhia das Letras, 2013. https://doi. org/10.4000/amerika.3507

SAUSSURE, Ferdinand de. Curso de linguística geral. São Paulo: Cultrix, 2006

SÜSSEKIND, Flora. Cinematógrafo das letras. Literatura, técnica e modernização no Brasil. São Paulo: Companhia das Letras, 1987. https://doi. org/10.2307/2516150

TELLES, Gilberto Mendonça. As duas estruturas da imagem literária. In: OLINTO, Heidrun Krieger; SCHOLLHAMMER, Karl Erik (org.). Literatura e imagem. Rio de Janeiro: Edições Galo Branco, 2005

\section{Endereço para correspondência:}

Alex Martoni

Centro de Ensino Superior de Juiz de Fora

Av. Barão do Rio Branco, 3520

Passos 36021-630

Juiz de Fora, MG, Brasil 